\title{
The Fatāwá in Islamic Banking and Financial Industry: Explaining the Use of Darürah (Dire Necessity) and Hẹajah (Need) Maxims
}

\author{
Muhammad Abubakar Siddique ${ }^{1 *}$, Abdul Rashid ${ }^{2}$ \\ ${ }^{1}$ Lecturer and Ph.D. Scholar of Islamic Banking and Finance, International Institute of \\ Islamic Economics (IIIE), International Islamic University Islamabad (IIUI), Islamabad, Pakistan \\ ${ }^{2}$ Associate Professor, International Institute of Islamic Economics (IIIE), \\ International Islamic University Islamabad (IIUI), Islamabad, Pakistan
}

\section{Keywords \\ Shar̄̄'ah Legitimacy \\ Darūrah \\ Hājah \\ Islamic Banking \\ Islamic Finance \\ Products}

Received: 3-Aug-19

Accepted: $30-\mathrm{Nov}-19$

\begin{abstract}
Sharī'ah objectives in relation to people are to secure interest of all and avert harm/hardship from them. These objectives have been taken care of in different Sharī'ah rulings. Regarding economics and finance, the principle of prevention of harm has been especially observed in the sphere of various Islamic contracts and business transactions. This study focuses on the use of maxims relating to darürah (dire necessity) and hājah (need), which redress the harm from people. Based on these maxims, Shari' 'ah scholars/committees have often been issuing the license of legality to several Islamic banking and financial transactions and products. The objective of the paper is to explain whether hājah and darürah are amalgamated concepts, and to find out the extent to which the maxims of hājah and darürah are being exploited in Islamic banking transactions and products. In so doing, the paper, through a literature review, differentiates hājah from darūrah. Analyzing the transactions and products as being used in Islamic Finance Industry (IFI), paper asserts that hājah, rather than darürah, is being entertained, and exploited to some extent. The paper also puts forward some suggestions for the stakeholders of Islamic banking and financial industry.
\end{abstract}

KAUJIE Classification: A6, B4, C2, C3, L2, K0

JEL Classification: I3, L14, Z12

(C) 2019 JIBM. All rights reserved.

\section{INTRODUCTION}

Sharī'ah is a vast encyclopedia of juristic rulings along with the mechanism and maxims relating to relaxation (rukhṣah) and permissibility (ibāhah) for odd situations. It was not a cakewalk for contemporary Islamic banking to reach its current position. It had to go through many difficult stages. New world of Islamic finance emerged facing different hurdles regarding its products, operations, contracts, and transactions. Sharī'ah scholars faced many

\footnotetext{
*Corresponding author: Muhammad Abubakar Siddique

†Email: muhammad.abubakar@iiu.edu.pk
} 
juristic challenges to guide the institutions how to meet their needs in the light of Shari 'ah. Keeping the newly engineered financial products Sharīa ah compliant, avoiding or removing the complexities and hardships is a difficult task.

Islam is the religion of relief (yusr) that facilitates human being in different fields of life under the Divine guidance (Al-Shatibi, 1997). Benefits, interests, and needs of human being are the main part of Sharī'ah objectives. The classical jurists analyzed the Shari' $a$ ah objectives parallel to the hardships which could be faced in obtaining these objectives. They ranked Sharī'ah objectives according to the severity of hardships and named them darürah (unavoidable necessity) or hājah (less essential desires) accordingly ${ }^{1}$. They also developed different principles and rules consequently. Many matters are in practice after extracting the license of legality under the Sharī'ah principles of darürah and hạjah. However, there is confusion about such matters whether they belong to the category of darürah or hājah, or none of the two and what could be the suitable verdict $(\mathrm{hukm})$ ?

\section{Background}

Contrary to conventional economic system, it is a unique feature of Islamic economic system that all of its affairs are covered under the Divine principles. It is mandatory that Shari' ${ }^{6}$ ah principles must be followed in true spirit and not circumvented. Therefore, a fatwá is required to justify every new embryonic matter in Islamic paradigm. Fatwá is known as the issuance of Sharī'ah opinion on behalf of the Holy prophet (PBUH) (Al-Shatibi, 1997). Contemporary Islamic banking emerged as an alternative of interest-based banking system. It brought new challenges to the Islamic world with respect to Sharí'ah compliance and permissibility of operations and offerings of Islamic Banks (IBs) and Islamic Financial Institutions (IFIs). Fatwá in Islamic finance is a legal device through which a competent Sharī'ah scholar extracts from Islamic sources any rulings on ambiguous matters through a process of $i j t i h \bar{a} d$ in the light of principles of Islamic jurisprudence (Lahsasna, 2011). Fatwá is a device that plays a vital role in ensuring that Islamic financial principles are being followed in IBs and IFIs in true spirit of Sharī'ah (Laldin, Khair, \& Parid, 2012). All IBs and IFIs are bound to follow the fatwá given by their Sharī'ah advisor/Sharī'ah board regarding their operations, products and services (Accounting and Auditing Organization for Islamic Financial Institutions, 2010, SS No. 29, clause 6/1, p: 510).

Over the last four decades, Islamic financial engineers have been playing a vital role in the development of new contracts to meet the need of newly emerged IFI. In so doing, they ask for fatwá from their Sharī'ah board to keep newly developed transactions and products Shari' 'ah compliant, and the Shari' 'ah boards guide them accordingly in the light of Sharī'ah principles. The critics like Abozaid and Dusuki (2007), Hussain and Choudhury (2007), Meera and Razak (2005), Wajdi (2009) and Zakariyyah (2012) are accusing Sharī'ah boards of exploiting the Sharī'ah maxims of darūrah and hājah to circumvent the Sharī'ah prohibitions of riba and gharar. Such criticism is defaming Islamic Banking and Finance Industry (IBFI) and creating false perception about it among people. According to Abozaid

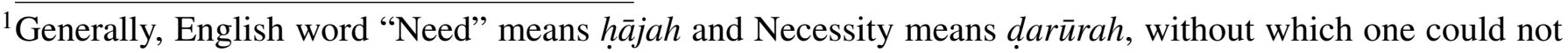
pull-on. 
and Dusuki (2007), Islamic banks exploited the Sharí'ah maxim of darūrah in their fatwá to get a legal excuse for products impermissible otherwise, e.g., bay ' bi-thaman ajil (deferred sales contract) and Islamic Pawn Broking. They argued how Islamic banks can launch products using maxim of darürah while people can survive without those products. If it is presumed that such products are necessary for the survival and long-term sustainability of IBFI due to certain considerations, then the argument is that very concept of bank itself is not indispensable for the people's survival from the Sharī'ah perspective. If the maxim of darürah supposedly exists in dealing with Islamic banks, then it would rather approve the dealing with conventional banks directly on the same grounds (Abozaid \& Dusuki, 2007). Majid (2011) says that takâful operators are using darūrah principle to get the legal excuse to commit prohibited deeds like obtaining covers from reinsurance companies of the conventional system.

The purpose of this study is to explain whether hājah and darürah are amalgamated concepts, and to find out the extent to which the maxims of hajjah and darürah are being exploited in Islamic banking transactions. The paper also highlights how to remove the obstacles of the impermissibility in many financial matters and to smooth the regulatory process for IBFI. It critically analyzes the banking and financial transactions and products that were pointed out by critics.

\section{DAR $\bar{U} R A H$ (DIRE NECESSITY) AND Hי̣̂̄JAH (NEED)}

According to Al-Shatibi (1997), maqāṣid do not go beyond three categories: al-darūriyyāt,

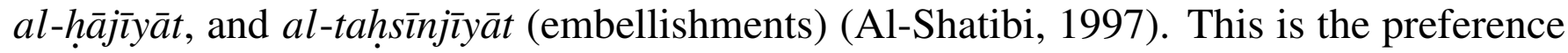
order, which facilitates the process of choosing and preferring one over the others, in case there is a conflict between them. This can be named as Al-Shatibi's (1997) theory of maqāsid preference. The first two categories are subject to relaxation to preserve the maqāssid alShari' 'ah in broader way, and it depends upon the situation and severity of matter. Therefore, this paper is limited to the first two categories only. In fact, the embellishments are not subject to rukhșah and al-takhfïf, so they do not fall under the scope of the paper.

\section{Darūrah}

Darürah, which represents the state of emergency, generally renders the prohibited things permissible as this constitutes a well-established fiqh maxim in the Sharī'ah "Necessities relax prohibitions". Classical and modern scholars consider darürah either in specific sense ${ }^{2}$ or in general sense ${ }^{3}$.

Al-Suyuti (1990) explains darürah as follows: "A person reaches such a situation that if he does not indulge in prohibited deed, he will die or reach close to death (then it would be darürah)". Al-Hamawi (1098H) confirmed this definition with bit different words. According

\footnotetext{
${ }^{2}$ Abubakr Al-Jassas (370H), Ibn al-Arabi (543H), Imam Fakhruddin Razi (606H), Al-Qartabi (671H), and Al-Suyuti $(911 \mathrm{H})$.

${ }^{3}$ Imam Ghazali (505H), Izz al-Din ibn Abd al-Salam (660H), Al-Shatibi (790H), Shaikh Abd al-Wahhab Khallaf (1375H), Abu Zahrah (1957) (p:43), Shaikh Mustafa Zarqa (1419), Al-Zuhaili (1975, p. 73), and Al-Raisuni (Muhadarat, p. 189-191)
} 
to Al-Shatibi (1997), "As for darūriyyāt, the meaning is that they must seek to establish interests of the $d \bar{i} n$ (hereafter) and this world, so that if they are missing, the interests of this world lose their harmony. In fact, their absence leads to corruption and trials as well as to the loss of life. In the Hereafter, it leads to the loss of success and blessings and reversion to manifest loss.

From the first definition, it becomes clear that one can indulge in prohibited activities entertaining the concept of darürah only to save one from death. To convey this concept of darürah, usually examples of pork or prohibited carrion are presented in the literature. In this scenario, darürah becomes limited to the situation of $i d t i r a \bar{a} r^{4}$. Consequently, it does not remain an appealing definition of darürah, because it ignores the equally important matters other than life, like the other Shari' 'ah objectives-narrows the vast concept of darürah into the life preservation. The second definition is not confined to just life, rather it includes all fields of life and all those cases where life is not in danger, but there is a big loss and trouble to life through affecting property, intellect, religion, and progeny.

Al-Raisuni (1995) explained Al-Shatibi's (1997) view that al-darūriyyāt are things which are necessary for the achievement of human beings' spiritual and material wellbeing. If these essentials are missing, the result will be imbalance and major chaos in both this world and the hereafter. Moreover, their lacking will cause greater or lesser corruption and disturbance in people's lives (p. 146). Abu Zahrah (1957) commendably explained the concept of darürah in following way: the necessity regarding life is to preserve the life and organs and all that without which life cannot be sustained, while necessity regarding the property and progeny is that without which property and progeny cannot be preserved.

\section{Häjah}

Al-Shatibi (1997) defined hājah in the words, "Complementary interests; people need them in terms of expansion and also to remove the hurdle often leading to severity and hardship which cause the loss of objective. If these interests are not observed, people will face severity and hardship, though, which will not reach at the level of total disruption of the public interest". He further says that hạjah is also acknowledged for 'ibādāt (worships), 'ādāt (Customs), jināyāt (punishments), and mu'āmalāt (contractual matters). Al-Zuhaili (1975) also explained and differentiated the hạjah from darürah. According to him, hạjah is considered beneficial to alleviate the hardships and severity from people, but its absence does not pose a threat to the life (Al-Zuhaili, 1975, p. 53). However, it is Ibn 'Ashur (1984) who defined hajjah comprehensively. According to him, "hạjah consists of what is required by the people for the realization of their interests and the proper execution of their affairs. The social order would not, in fact, collapse, but will not function properly, if it is ignored. Likewise, hājah is not on the level of darürah.

In simple words, the hājah is subordinate to darürah (Zarqa, 1989, p. 209) and it grants legal excuse from hardship, so that one can enjoy a life free from distress and predicament. According to Al-Raisuni (1995, p. 146), al-ḥajjìyāt are the interests which, when fulfilled, contribute to relieving hardships and difficulty and creating ease in the lives of mukallafin

${ }^{4}$ Idtirāar is a state of being forced or being coerced in which one's death is certain otherwise 
(those who are accountable before the law).

\section{THE DIFFERENCE BETWEEN DִARŪRAH AND Ḥִ̂̄JAH}

In addition to the above discussion, we indicate the following differences between darürah and hājah:

1. The relaxation granted in case of hājah remains everlasting, but it would remain temporary in case of darürah (as necessities are estimated according to limits there under) (Zarqa, 1989, p. 209). Al-Zuhaili (1975) also confirmed the opinion that relaxation granted in case of hājah remains everlasting.

2. Darürah can be effective in permitting things which are prohibited by default (harām bi al-dhāt) such as using alcohol, and eating pork, while hạjah can be effective only in things which are prohibited by external factors (harām bi al-ghaīr) such as to say prayer in a snatched land is permissible (Abu Zahra, 1957). Organisation of Islamic Cooperation Fiqh Council (2000) passed the resolution no. 50/1/6: House is a basic human need (hājah). This need should be fulfilled through legitimate means by lawful (halāl) money. The method of advancing loans on interest adopted by the real estate and housing banks or other financial institutions is prohibited under Sharī'ah, no matter how high or low the interest rates may be, because this method is based on rib $\bar{a}$ (usury) transaction and it cannot be allowed on the basis of hạjah, because hạjah cannot make harām bi al-dhāt things permissible.

3. According to Ibn al-Qayyim (1991), hạjah makes permissible what is prohibited as a protective measure (sadd al-dhari ${ }^{6} a h$ ) for public interest, while what is prohibited by clear text can only be permitted by virtue of darürah.

4. Darūrah provides a legal excuse regarding matters, which are announced harām by Qur'ān and Sunnah. The case of hājah is different in a way that it grants legal excuse in matters which often do not contradict with Qur'ān and Sunnah, but with general principles (qawā' id 'ämmah).

5. Darūrah includes hājjah, but not vice versa, as Al-Shatibi (1997) says that an imbalance

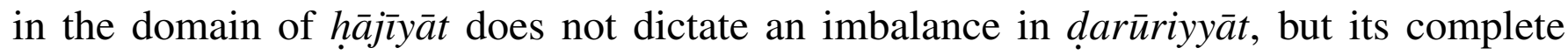
imbalance may cause partial disturbance in darūriyyāt. While a little disorder in darūriyyāt will lead to complete imbalance in hiajīy $\bar{a} t$.

From this discussion, it becomes clear that darürah and ḩajjah are not amalgamated concepts. Both have different conditions and applications. Researchers and critics should think on these guidelines in their analysis and Islamic financial engineers should keep these prerequisites in their view before entertaining the hạjah maxim.

\section{ELEVATION OF Ḥִ̂̄JAH TO THE LEVEL OF DִARŪRAH}

Islamic jurists are of different opinions whether both, or only hăjah ' $\bar{a} m m a h$ could be elevated to the level of darūrah. In the opinion of Al-Juwayni (1997), hạjah 'ämmah is considered equal to darürah when it is collective and universal. He denied such elevation of hajjah khașsah in favor of individuals. Al-'Anzi (2015) said that only hājah 'ämmah can make a harām thing permissible, if it is close to halāl like ijārah, otherwise it cannot make it 
permissible the prohibited like eating pork, taking one's property through unfair means, and adultery. Such acts cannot be allowed on the basis of hajjah, because all these deeds are far from the state of haläl. Therefore, the principle of Al-Juwayni (1997) is not in absolute term. Al-Zarkashi (1985) says that häjah khașah also makes prohibited things permissible and calls for relaxation in the original law and justifies departure from it. Later, Al-Suyuti (1990) combined both qawā' id, that of Al-Juwayni (1997) and Al-Zarkashi (1985) and presented new qawa' id that hajjah, whether general ('ämmah) or specific (khassah), is considered as darürah. Ibn Nujaim (2011, p. 114) also adopted the same view of Al-Sayuti in his Al-Ashbah. hajjah khașah is the need faced by a particular community or the peoples of particular profession as the need faced by the people of Bukharah to obtain loans through redeemable sale (Majallah al-Ahkam al-'Adliyyah, p. 19). Unlike darürah, the hardship in case of hajjah is not so extreme as to endanger life or limb (Mansuri, 2007; p. 106).

After it has been established that hājah, either general or specific, sometimes reaches at the level of darūrah to extract the permissibility (ibāhah) in matters that are harām bi al-ghaīr, and still such strong ḥajjah will remain ineffective in harām bi al-dhāt matters or things like ribā. If anything is considered hăjah equal to darürah in any special case, it would be subject to the rules of darürah which constitute that provision of relaxation would be temporary, not for ever. Al-Shunqaiti (2007), a Hanbali Scholar, is of the view that zakāh payment can be delayed if its spot payment may cause loss in asset of a person. He built his view on the basis that such situation is hajjah equal to darürah in favor of the person. Therefore, he can delay in zakāh payment until threat of loss is removed, because that was a temporary permission as darürah grants temporary permissions only.

\section{USE OF HיĀJAH MAXIM IN ISLAMIC BANKING AND FINANCE}

Social, economic, and financial matters of classical as well as modern times always propped up by Sharī'ah rules of relaxation which are derived from primary sources of Islam. Some financial transactions and contracts in which hăjah is being entertained are given below;

1. To avoid buy back in Murābahah to Purchase Order (MPO), it is not recommended for Islamic banks to appoint the client as an agent because "a party cannot become buyer and seller in same contract" (Al-Kasani, 1986). AAOIFI Sharī'ah standard considers it permissible in the situation of need (hājah) (Accounting and Auditing Organization for Islamic Financial Institutions, 2010, SS No. 8, clause 3/1/3, p. 119). In case of appointing the third party as agent, Islamic banks apprehend that client of MPO (orderor) might refuse to buy promised item if he disliked and it would be injurious to the banks. Therefore, AAOIFI considered it genuine hăjah for Islamic bank to appoint its client as agent to buy ordered goods and called for relaxation in original law of prohibition.

2. The jurists have difference of opinion regarding the permissibility of opening documentary credit. According to opponent jurists, documentary credit pertains to the category of delaying counter values in ribāwi items, which is not permissible in Sharī'ah (Accounting and Auditing Organization for Islamic Financial Institutions, 2010). However, documentary credit has become essential part of international trade and it facilitates the payments. Two-dimensional risk is involved in it that can be mitigated through the documentary credit 
and counter parties remain satisfied through this device. Keeping in view this importance, AAOIFI considered documentary credit permissible on hạjah basis.

3. According to AAOIFI Sharī'ah standard, it is necessary to cease or dispose of the impermissible transaction immediately and it is not allowed to delay. However, at the same time, AAOIFI allows this delay if it is necessary (darürah) or pressing need (hājah) (SS No. 6 , clause $2 / 1$ and 3/f, p. 83-84). Usually conversion of conventional bank to an Islamic bank takes some time. Therefore, AAOIFI Sharī'ah standard used the term darūrah in this regard. Such delay can be become pressing need (hājah equal to darürah) which would be limited to the extent of magnitude of the need. That is why, AAOIFI Shari' ah standard says "any dealing with conventional banks must be limited to the magnitude of the need to do so" (SS No. 6, clause 3/f, p. 84).

4. Application of $j u^{\prime} \bar{a} l a h$ in exploration for minerals, extraction of water, collection of debt, brokerage, discoveries, innovation and designs, is permissible on the basis of general need (hājah 'ämmah), because it was basically permitted as a reward for the return of runaway slave, as is mentioned in Sunnah. That is the reason that some of jurists restricted it with runaway slave situation only. According to AAOIFI's SS, it is allowed based on general need (hājah 'ämmah) (Accounting and Auditing Organization for Islamic Financial Institutions, 2010).

5. Dealing in commercial papers, bill of exchange, promissory note, and bank cheque, is permissible on the basis of hajjah. Commercial papers are loan-based instruments and belong to the category of suftījah (Accounting and Auditing Organization for Islamic Financial Institutions, 2010) which is an instrument in which a creditor stipulates another place for the settlement of the loan (Salim, 2013). Imam Al-Shafi'i (204H) considered it illegal. Malikis considered it permissible, if it is necessary for the protection of property otherwise it would be impermissible (Al-Zuhaili, 1985). Hanbali jurists allowed it if executed without any consideration in other city (Ibn Qudamah, 1997). Hanafi considered it disliked (makrūh), if it is stipulated with loan (Al-Sarakhsi, 1989). According to Ibn Taymiyyah (728H), there is no text (nașs) against or in favor of the permissibility of suftijah, so it is necessary to maintain its permissibility (ibāhah), especially when there is a general need (hājah) for it (Accounting and Auditing Organization for Islamic Financial Institutions, 2010).

6. According to classical Ahnaf, a unilateral promise is not binding. Yet, according to Ibn 'Abdin (1992) promises some times are considered binding because of hạjah of people (Ibn 'Abdin, 1992). In case of non-binding promise in MPO, a client can cause a harm to an Islamic bank by refusing to buy after Islamic bank buys an asset on his order in muräbahah. That is why, in today's banking and financial contracts, unilateral promises are taken as binding on promising party because of such häjah.

7. Jurists, based on hạjah, allowed financial penalty in case of failure of the debtor in paying when due. Nadwah al-Barkah (2002) passed a resolution according to which creditor should relax the borrower regarding time, if the liability to pay has resulted from any sale contract or exchange transaction subject to deferred payment, the debtor can be asked to pay fine in unjustified late payment (p. 103) which has to be credited to charity account (State Bank of Pakistan, 2008) as some Maliki jurists say that a delaying borrower should be 
obliged to pay for charitable activities (Accounting and Auditing Organization for Islamic Financial Institutions, 2010). The Organisation of Islamic Cooperation Fiqh Council (2000), however, resolved that penalty provision would be ineffective when a client proves that he could not pay on time due to a reason beyond his control, or when he proves that the bank incurred no loss as a result of his breach of the contract (Resolution No. 109 (3/12). Now the question is whether aggrieved party can be compensated by this penalty amount or not? Chapra and Khan (2000) mentioned a view of some scholars who allow taking penalty from defaulter in case of unjustified delay, but they also allow passing on the penalty amount to the aggrieved party as compensation, if penalty is imposed by a court. According to one resolution of Al-Barakah seminar, bank can be compensated for its actual loss caused by client's delay (Al-Barakah, 2002), but cannot be paid the 'opportunity cost'. The point to be made here is that penalty clause application is permitted on the basis of hajjah.

8. Kafālah bi al-dark is also considered permissible on the basis of hajjah. Kafālah bi al-dark is a guarantee by seller, that he will return the price of object if someone claims on that object. This guarantee may also be from third party in favor of seller that he will offset the loss of buyer in case of claim by real owner (Mansuri, 2007; p. 113).

\section{MISUSE OF HĀA JAH MAXIM IN ISLAMIC BANKING AND FINANCE}

\section{Wa'dān based Islamic Foreign Exchange Forward Contracts}

The term Wa'dān means that two parties makes two unilateral and independent promises to each other in a particular deal and their respective fulfillment depends on two independent conditions. This concept is applied in foreign exchange forward contracts in Islamic finance. In fact, it was Nadwah al-Barkah (1981) who issued fatwa "If two promises are binding on both parties, then it falls within the prohibition of selling a debt for a debt and is, thus, not permitted. However, if it is not binding on either party then it is permitted". Of course, they did not provide any Sharī'ah base of this fatwá. However, Aznan et al. (2008) suggested to entertain hạjah ' $\bar{a} m m a h$ maxim to get legal excuse for the product of Islamic foreign exchange forward contract based on $W a^{\prime} d \bar{a} n$ (promises by the both contracting parties). Ahmad, Salmy, and Mat Noor (2014) also confirmed it and commented that this wa'dān based product has become the pressing need (hājah 'āmmah) for the public in general, so this product should be allowed only on the basis of hajjah and this permission should be limited to hedging purpose only. Aznan et al. (2008) and Ahmad et al. (2014) did not provide rationale for allowing the contracts based on promises by the both exchange parties. It is not possible that two promises in same contract and same dealing will remain unilateral and independent of each other. Their interdependency implicitly does exist in case of the same contract. Binding nature on the both sides implies that a contract has been allowed vide a strategy, that otherwise was prohibited. Practically, these two promises constitute bilateral promises which lead to a contract. In this way, it leads to the situation of contingency between the contracts. Holy Prophet (PBUH) prohibited two contracts in one contract (Al-San'ani, 1983). Ha ājah can be employed only if there is no opposite explicit text, while there is a certain text (Sunnah) against it. Therefore, $w a^{\prime} d \bar{a} n$ based Islamic foreign exchange forward contracts should not 
be granted the license of permissibility using the hājah maxim, particularly, because the IFIs have started using the same for investing in financial derivatives without the need for hedging and without fulfilling the conditions of underlying contracts (Anwer \& Habib, 2019).

\section{Bay' al-mu'ajjal of GOP Ijārah Șukūk}

Government of Pakistan (GOP) has been issuing fixed rental rate GOP Ijārah șukük for about a decade. For the three years maturity period $s u k \bar{u} k$, Jinnah International Airport Karachi (JIAK) was sold to Special Purpose Vehicle (SPV). GOP got same terminal on lease with the binding promise to purchase the JIAK at the end of lease. SPV issued Ijärah sukūk and sold them to Islamic banks and the money paid to GOP. GOP Ijārah Șukük were also tradable in secondary market, but it was rare for Islamic banks to sell them because they wanted to hold till maturity to retain investment giving them secure return. As GOP did not issue new ijārah $s u k \bar{u} k$, and did not renew the old one, practitioners and treasury officials of Islamic banks got worried that liquidity of Islamic banks would remain idle and un-invested after GOP Ijārah $S u k \bar{u} k$ matured. As discussed in the Ayub (2015), a way out was suggested to the Shari' 'ah Board of SBP according to which șuku $k$ would be sold, sometime before maturity, to the SBP for the period of one year on credit basis (bay 'al-mu'ajjal) in such a way that the seller bank would add one year's T-bills related rate to the face value and the rental receivable by that time. He further contended that if $s u k \bar{u} k$ could be sold on credit for one year, the same could be for any maturity e.g. five or even ten tears.

According to Asim et al. (2018), SBP allowed the bay' al-mu'ajjal of GOP Ijārah Șukūk keeping in view the need (hajjah) of Islamic financial institutions with respect to liquidity management. The concerns of scholars seem apparently to be valid because basic purpose of this credit sale of GOP Ijärah Sukūk is to earn from the receivable. But, the issue is that earning on receivables/debts amounts to ribā. In that case, it is only a subterfuge (hịlah) to circumvent the prohibition of riba and is being adopted in the name of hajjah to invest Islamic banks liquidity. Ayub (2015) indicated that it was irrational sale contract of ijārah șukuk when Islamic banks don't remain owner of the asset after maturity and asset is re-purchased by GOP, how Islamic banks can get rental over same asset for any period after maturity while knowing that the even the subject of the sale would not be in their possession and risk. Moreover, GOP Ijārah Șukūk represented debt receivable upon maturity, and not an asset for a valid sale. Therefore, GOP Ijärah Șukük cannot be traded after maturity except only on hawālah basis. On the other hand, in credit sale of GOP Ijārah Sukūk, the seller banks added one year's T-bills related rate to the face value and rental receivable by that time ( $\mathrm{p}$. 181-186).

Salman Syed Ali, Senior Research Economist at IRTI, IDB, Jeddah, as a discussant on the matter says, in this regards, "Any party that is buying the sukük just before its maturity date (i.e., the date of its automatic transformation into cash) and it is willing to pay a higher amount (than the cash receivable from retirement of $s u k \bar{u} k$ ) if allowed to make the payment on a deferred time; it is violating ahkām al-șarf (rules of ribā al-faḍl). Hence, sale of șukūk just before maturity on a price contractually deferred beyond the maturity date of the șuku $k$ is prohibited". "However, a planned buy very near to the maturity date such that the $s u k \bar{u} k$ 
are held only for a short time with intact tangible underlying asset and for a longer planned time without a tangible underlying asset while earning a return falls under prohibition zone". "The Open Market Operation (OMO) arrangement has been made to keep the money invested to earn a return beyond the maturity date, into a period when the $s u k \bar{u} k$ have transformed from representing a real asset to pure cash (or cash receivable or liquid) asset. This intension is not simply hidden, but made explicit in the policy evidenced by the arrangement to do it regularly and on a large scale. Thus, the arrangement is not Sharī'ah compliant", he adds (Ayub, 2015).

Particularly, the following concern expressed by Syed Ali is worth noting: "A seemingly small move by the SBP to accommodate an incidental need of return-generating short-term liquid asset for Islamic banks is going to create a hole that will open the floodgates of wrong practices and undermine some core values of Islamic finance". We reiterate, therefore, that riba $\bar{a}$ belongs to the category of harām bi al-dhät, and need (hâjjah) cannot be invoked for granting legal excuse in harām bi al-dhāt matters. Therefore, sale of GOP Ijārah Șukük on the basis of bay al-mu'ajjal should not have been granted license of legality.

\section{WAY FORWARD}

According to Mansuri (2007), jurists generally leave hạjah maxim to the person or institution facing the situation and it leads towards the manipulation of this maxim. He suggests that to avoid such manipulation of hājah maxim, in legislation, it seems appropriate that a competent body of Muslim scholars, instead of few scholars, should frame concessionary laws, based on häjah ascertaining its necessity and magnitude (p. 117).

Mostly such exploitations and manipulations of Sharī'ah maxims and principles are caused by Shari'ah advisors/committees that might not be having enough knowledge of modern economics and finance. There may be other factors like pressure by the management of the banks and the conflict of interests of Shari' 'ah board members with concerned bank. This matter is related to regulatory authorities that must focus on developing separate and foolproof regulations for Islamic banking and financial institutions so that the maxim of $h \bar{a} j a h$ is not entertained to circumvent the prohibitions. It is also matter of concern for the Sharī'ah scholars, because such practice is adversely affecting their credibility into the public. They have to equip themselves with enough knowledge in the field of modern banking and finance.

Further, the Shari' 'ah advisory system has to play its role properly. Sometimes, such products are allowed in the name of need and ijtihād that clearly violate Sharí ${ }^{-}$ah principles. Adherence of the principles of Islamic finance must be ensured. Ayub (2016) expressed concern on flexible approach of the Sharī'ah advisors issuing fatāwá for launching of products like currency Salam and Running Mushärakah as replica of bill-discounting and the conventional overdraft, respectively. He concluded that regulators needs to focus on policies to control the Shari' ${ }^{-}$ah advisors regarding replication of conventional interest based prohibited products, because it is damaging the credibility of Islamic finance. 
To develop strong Islamic financial industry, it is suggested for the regulatory authority that hiring of Sharī'ah board members must not be left on the discretion of the concerned Islamic bank. Sharī'ah advisors/board members must be paid through central bank to make their fatāwá unbiased. It would enhance financial inclusion, and credibility of Islamic banks and would be helpful in enhancing their customer base.

There must be proper educational criteria at degree level and scholars having conventional economics, banking and finance education as well as proper Sharī'ah education should be preferred. The existing criterion for eligibility of Shari' ah board members says "adequate understanding of banking and finance in general and Islamic finance in particular" (State Bank of Pakistan, 2018). It leaves loophole, because "adequate understanding" cannot be judged and can be compromised. Therefore, degree level (BS/MS/PhD) education in economics/Banking/Finance/Islamic banking \& Finance must be required along with solid research work/papers/book and degree of Shahādat al-'ālamìyah (Sharī'ah education).

\section{CONCLUSION}

Darūrah and hạjah are not amalgamated concepts. Each concept has its own prerequisites, which must be met before entertaining the related Sharí 'ah maxim. Islamic financial engineers, regulators, researchers and critics should keep in view this difference between these two concept before developing financial product, regulation, research and criticism, respectively. However, some of Islamic banking transactions and products have been found exploiting the maxim of hājah. Day by day changing business environment, circumstances, values, culture, custom ('urf), needs and life style are witness that nothing is subject to status quo. Today, business and trade matters are different and more complex as compared to the classical times. Islamic sources are very rich and flexible enough to meet the need of every time. Accordingly, it becomes necessary to carefully consider the financial needs of modern times at both individual and institutional levels, so that new Sharī'ah rulings regarding business, trade, economics and financial matters remain within the Shar ${ }^{-}$'ah parameters and serve the maqāṣid al-Sharī'ah.

\section{REFERENCES}

Abozaid, A. \& Dusuki, A. W. (2007). The challenges of realizing maqasid al-Sharī'ah in Islamic banking and finance. Paper presented at the IIUM International Conference on Islamic Banking and Finance, Kuala Lumpur, Malaysia.

Abu Zahrah, M. (1957). 'Usul al-fiqh. Beirut, Lebanon: Dar al-Fikr al-Arabi.

Accounting and Auditing Organization for Islamic Financial Institutions. (2010). Sharī'ah standards for Islamic financial institutions. Retrieved from https://bit.ly/2HXofLT Ahmad, A. A., Salmy, E. Y., \& Mat Noor, M. Z. (2014). The use of wa'dan in Islamic contract FX forward: Weighting between Maslahah and Mafsadah. Asian Social Science, 10(22), 332-342. doi: https://doi.org/10.5539/ass.v10n22p332

Al-'Anzi, M. (2015). Qaidah: Al-hajah al-'amah tanzilu manzila al-darurat al-khassah. Retrieved from https://bit.ly/2TtxCIm 
Al-Hamawi, A. M. (1098H). Ghumzu 'uyun-il-basa'ir. Bairut, Lebanon: Dar-ul-Kutub Al-Ilmiyyah.

Al-Juwayni, A. M. (1997). Al-burhan fi usul al-fiqh. Bairut, Lebanon: Dar-ul-Kutub Al-Ilmiyyah.

Al-Kasani, A. (1986). Badai' al-sanai'. Berut, Lebanon: Dar al-Kutub al-Ilmiyyah.

Al-Raisuni, A. (1995). Nazriyyah al-maqasid 'inda al-shatib. Herndon, VA: International Institute of Islamic Thought.

Al-San'ani, I. A. R. (1983). Al-musannaf. India: Almajlis al-Ilmi, 1983.

Al-Sarakhsi, M. A. (1989). Al-mabsut. Berut, Lebanon: Dar ul M'arifah.

Al-Shatibi, S. A. I. (1997). Al-muafaqat. Al Khobar, Saudi Arabia: Dar Ibn 'Affan.

Al-Shunqaiti, M. A.-M. (2007). Sharh zad al-mustaqni'. Tehran, Iran: Al-Ri' asah al-'amah Lil buhus al-'ilmiyyah wa al-ifta.

Al-Suyuti, I. J. D. (1990). Al-ashbah wa al-naza'ir. Berut, Lebanon: Dar al-Kutub AlIlmiyyah.

Al-Zarkashi, B. D. (1985). Al-Manthur fi al-qawa'id. Kuwait: Turath For Solutions.

Al-Zuhaili, W. (1975). Nazariyyah al-darurah al-shari' 'yyah. Berut, Lebanon: Mu'assasat Al-Risalah.

Al-Zuhaili, W. (1985). Al-Fiqh al-Islami wa Addillatuhu. Berut, Lebanon: Dar al-Fikr.

Anwer, Z., \& Habib, F. (2019). Re-visiting current debate on Sharī'ah position of derivatives. Journal of Islamic Business and Management, 9(1), 64-83.

doi: https://doi.org/10.26501/jibm/2019.0901-005

Asim, M., Iqbal, K., Raza, K. M., \& Obaidullah, Q. (2018). Effects of bai mu'ajjal transactions on interest rate under șukuk-backed open market operations conducted by SBP for liquidity management of IBIs in Pakistan. COMSATA Journal of Islamic Finance, 3(1), 1-20. doi: https://doi.org/10.26652/cjif.3201811

Ayub, M. (2015). Bai' al-Mu'ajjal of GOP ijārah șukūk-liquidity management product of the state bank of Pakistan [JIBM discussion forum]. Journal of Islamic Business and Management, 5(2), 181-194.

Ayub, M. (2016). Focusing on Sharī'ah governance in regulating the Islamic banking Institutions [Editorial]. Journal of Islamic Business and Management, 6(2), 07-18.

Aznan, H. (2008). Wa'ad, Wa'dan dan muwa'adah. Presented at Muzakarah Cendekiawan Syariah Nusantara Kali Ke-2, Anjuran Bank Negara Malaysia, Kuala Lumpur, Malaysia. Chapra, M. U., \& Khan, T. (2000). Regulation and supervision of Islamic banks. Jeddah, Saudi Arabia: Islamic Research and Training Institute.

Hussain, S., \& Choudhury, T. (2007). Muslims in EU: Cities report United Kingdom. Retrieved from https://osf.to/32J40Li

Ibn 'Abdin. (1992). Rad al-muhtar. Berut, Lebanon: Dar al-Fikr.

Ibn 'Ashur, M. T. (1984). Al-tahrir wa al-tanvir. Tunis, Tunisia: Al-Dar al-Tunasiyyah Li al-Nashr.

Ibn al-Qayyim, M. A. (1991). Al-jawziyyah. i'lam al-muwaqqi'in 'an Rabb al-'Alamin. Berut, Lebanon: Dar-ul-Kutub Al-Ilmiyyah. 
Ibn Nujaim, Z. A. (2011). Al-ashbah wa al-naza'ir. Berut, lebanon: Al-Maktabah al'asriyah.

Imam Al-Shafi‘i. (204H). Al- 'um. Berut, Lebanon: Dar al-Ma'rifah.

Izz al-Din ibn Abd al-Salam. (660H). Qawa 'id al-ahkam fi masalih al-anam. Cairo, Egypt: Maktabah al-Kulliyyat al-Azhariyyah.

Lahsasna, A. (2011). Fatwa and its Sharī'ah methodology in Islamic finance. Journal of Fatwa Management and Research, 2(1), 133-179.

Majallah al-Ahkam al-'Adliyyah. Karachi, Pakistan: Noor Muhammad, Karkhanah-eTijarat-eKutub.

Majid, M. (2011). Special column with adjunct professor of FEM: Datoy Majid Mohamad [Interview]. Retrieved from https://bit.ly/2PIqAOW

Mansuri, M. T. (2007). Shar̄̄‘ah maxims on financial matters. Islamabad, Pakistan: Sharı̄‘ah Academy, IIUI.

Meera, A. K. M., \& Razak, D. A. (2005). Islamic home financing through musharkah mutanaqisah and al-Bay' bithaman ajil contracts: A comparative analysis. Review of Islamic Economics, 9(2), 5-30.

Nadwah al-Barkah. (1981). Qararat wa tawsiyat: Nadwat al-barkah lil-iqtasad al-Islami. Retrieved from https://bit.ly/2uNdb0G

Nadwah al-Barkah. (2002). Resolutions and recommendations on Al-Baraka symposia for Islamic Economy. Retrieved from https://bit.ly/2PJpwtY

Organisation of Islamic Cooperation. (2000). Resolutions and recommendations of the council of the Islamic fiqh academy 1985-2000. Jeddah, Saudi Arabia: Organisation of Islamic Cooperation.

Salim, M. Y. (2013). Islamic commercial law. Singapore: Wiley \& Sons.

State Bank of Pakistan (2018). Shar'`'ah governance framework for Islamic banking institutions. Karachi, Pakistan: State Bank of Pakistan.

State Bank of Pakistan. (2008). Instructions for Sharī'ah compliance in Islamic banking. Karachi, Pakistan: State Bank of Pakistan.

Wajdi, A. (2009). Challenges of realizing maqasid al-Sharī'ah (objectives of Sharī'ah) in Islamic capital market: Special focus on equity-based $s u k \bar{u} k$. Paper presented at the 3rd USM-ISDEV International Islamic Management Conference on Islamic Capital Market, Centre for Islamic Management Studies University Saints Malaysia, George Town, Malaysia.

Zakariyyah, L. (2012). Necessity as a pretext for violation of Islamic commercial law: A scenario of mortgage contract in the UK. Journal of Islamic Economics, Banking and Finance, 8(1), 35-53.

Zarqa, A. (1989). Sharh al-qawaid al-fiqhiyyah. Damishq, Syria: Dar al-Qalam. 